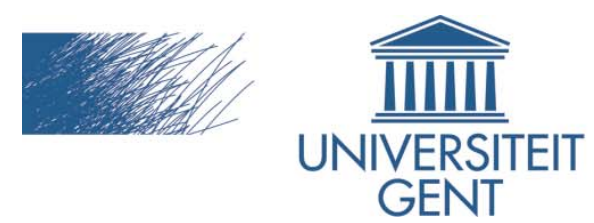

biblio.ugent.be

The UGent Institutional Repository is the electronic archiving and dissemination platform for all UGent research publications. Ghent University has implemented a mandate stipulating that all academic publications of UGent researchers should be deposited and archived in this repository. Except for items where current copyright restrictions apply, these papers are available in Open Access.

This item is the archived peer-reviewed author-version of:

Personal determinants of organic food consumption : a review

Aertsens, J., Verbeke, W., Mondelaers, K., Van Huylenbroeck, G.

In: British Food Journal, 111 (10), 1140-1167, 2009.

To refer to or to cite this work, please use the citation to the published version:

Aertsens, J., Verbeke, W., Mondelaers, K., Van Huylenbroeck, G. (2009). Personal determinants of organic food consumption : a review. British Food Journal 111 (10), 11401167. 10.1108/00070700910992961 


\title{
Personal determinants of organic food consumption: a review
}

\section{Published as...}

Aertsens, J., Verbeke, W., Mondelaers, K., Van Huylenbroeck, G.; 2009; "Personal

determinants of organic food consumption: a review"; British Food Journal; Volume: 111 (10);

pp. 1140-67;

http://www.emeraldinsight.com/10.1108/00070700910992961

Keywords: consumer, theory of planned behaviour, values, attitude, norm, involvement, organic

Category: Review.

\begin{abstract}
Scope and objective:

A lot of literature is available that discusses personal determinants of organic food consumption. However different models and determinants are used in the literature. In this paper an overview is provided, within a framework linking Schwartz' Values Theory and the Theory of Planned Behaviour (TPB). Also attention is given to the importance of affective attitude, emotions, personal norm, involvement and uncertainty related to organic food consumption.
\end{abstract}

\section{Methodology/Approach:}

The paper is based on secondary data sources, namely the literature concerning personal determinants of organic food consumption.

Findings: Both the Values Theory and the Theory of Planned Behaviour have been referred to as relevant theories for better understanding consumers' choice for organic food. Organic food consumption decisions can be explained by relating attributes of organic food with more abstract values such as "security", "hedonism", "universalism", "benevolence", "stimulation", "selfdirection" and "conformity". Appealing to these values can positively influence attitudes towards organic food consumption. Besides attitude also subjective and personal norm and (Perceived) Behavioural Control influence consumption of organic food. Relatively little research has examined the affective component of attitude and emotions in relation to organic food consumption, while these may play an important role as drivers of involvement and thus help to jolt food purchasers out of their routine of buying conventional food and set a first step to adopt organic food. Also more research related to the role of uncertainty (reduction) during the process of buying organic food, is recommended.

Originality / Value of the paper/ Practical implications:

To our knowledge, this is the first paper providing a comprehensive overview and linking the literature on organic food consumption to the Values Theory and the Theory of Planned Behaviour, including the role of personal norm and focusing on emotions. The proposed integration of mental processing in an organic food consumption model leads to interesting hypotheses and recommendations for policy makers, researchers and stakeholders involved in the organic food market. 


\section{Introduction}

While most consumers hold positive attitudes towards organic food (Magnusson et al., 2001, Saba and Messina, 2003, Kihlberg and Risvik, 2007), the proportion of consumers purchasing organic food on a regular basis remains low, with market shares of organic products in European countries, varying from below one percent in some Southern, Central \& Eastern European countries to over five percent in Austria and Denmark (Sahota, 2009, Padel et al., 2009).

Since the 1990s research concerning the determinants of organic food consumption has gained momentum. In the first references, organic food consumption was mainly approached by applying the Values Theory of Rokeach (1973) and Schwartz (1992). More recently, researchers also tested the Theory of Planned Behaviour (TPB) (Ajzen, 1991) as a possible model for explaining organic food consumption. In section 2 of this paper, we briefly present both models and indicate how values interact with planned behaviour factors. In this paper, we develop an integrated framework (Figure 1), of which the core is an adapted TPB model, including the role of values, beliefs, personal norm, emotions and experience. The different links indicated in the framework will be further discussed in the consecutive sections of this paper. In section 3, this integrated framework is used to structure the relevant literature on personal determinants of organic food consumption while in section 4 we discuss the role of involvement and uncertainty on the mental processes related to organic food purchases. Section 5 presents a discussion with recommendations for policy makers and other stakeholders in the organic market.

Figure 1: Integrated Framework on personal determinants of organic food consumption

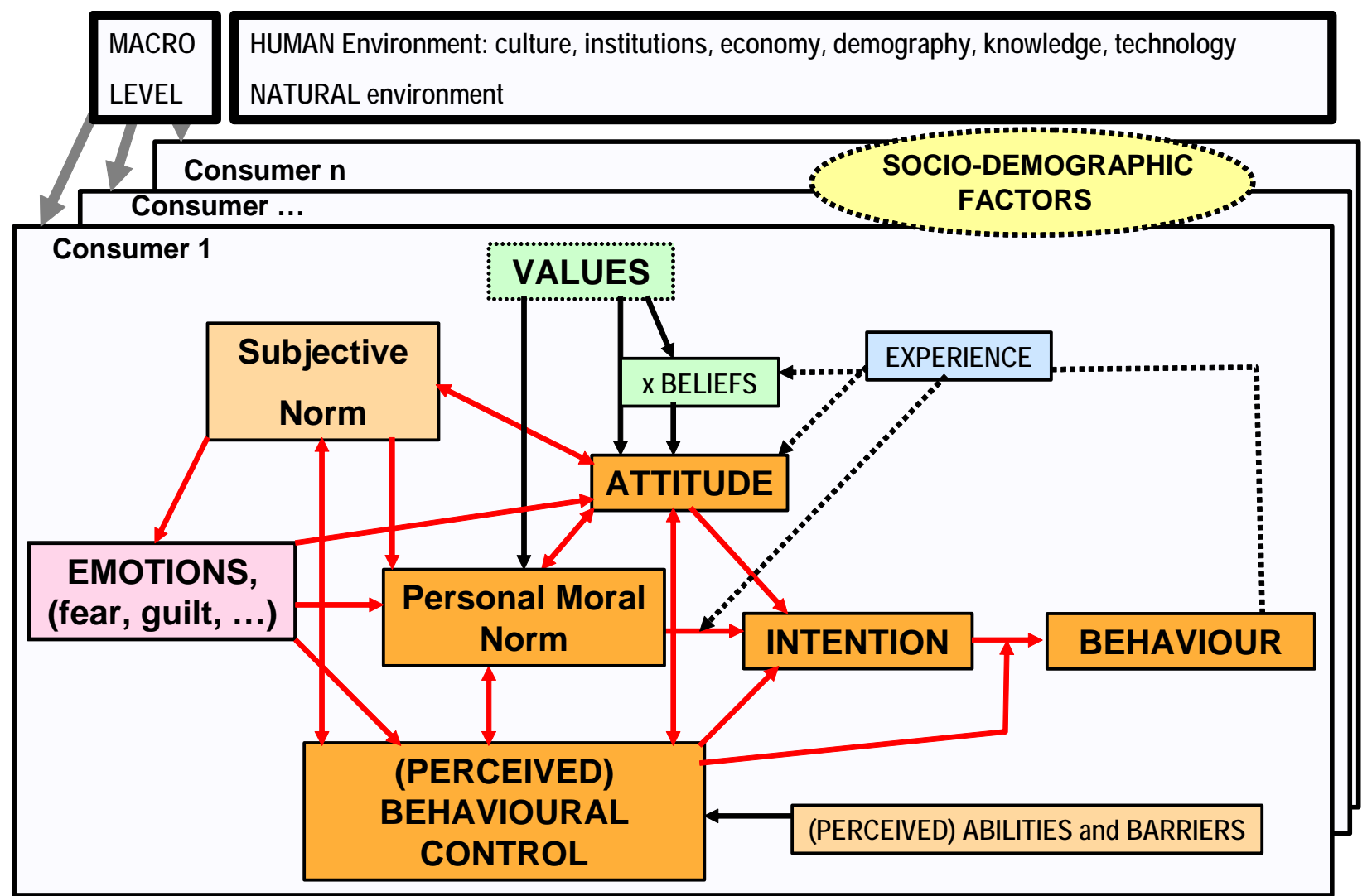

Source: Adapted TPB-model based on the literature related to organic food consumption 


\section{TPB and Values Theory as framework}

The Theory of Planned Behaviour (Ajzen, 1991) is a generally applied model that predicts behaviour based on "intention to perform the behaviour" and "(Perceived) Behavioural Control". Intention is influenced by three constructs "Attitude towards the behaviour", "Subjective Norm" and "Perceived Behavioural Control (PBC)". TPB has often been applied in the area of food choice and more recently also to model organic food choice (Saba and Messina, 2003, Tarkiainen and Sundqvist, 2005, Chen, 2007, Gracia and de Magistris, 2007, Thøgersen, 2007a, Dean et al., 2008).

The Values Theory (Rokeach, 1973, Schwartz, 1992) has also been applied to get better insight in the consumption of organic food. Schwartz (1992) defines a value as "a desirable transsituational goal varying in importance, which serves as a guiding principle in life ...". Based on several decades of psychology research Schwartz $(1992,2006)$ proposed 10 basic motivational values that incorporate virtually all specific values from different cultures around the world. The 10 values are derived from universal requirements for humans as biological organisms and as social interactive individuals as part of social groups striving for survival and welfare. The Schwartz Value Inventory (Schwartz, 1992) is very often used to study the link between values and consumer behaviour. The abstractness of the value concept and its main features make it especially attractive for cross-cultural research. Cultural differences in specific behaviours are more easily explained by referring to more abstract levels of the cognitiveemotive hierarchy (Beckmann and Hansen, 1999). Values are generally understood as extremely stable constructs, and therefore values can serve as better predictors of behaviour over extended periods of time (Krystallis et al., 2008). In order to study the values that influence consumption behaviour researchers can apply the means-end theory (Gutman, 1982, Costa et al., 2004) and laddering techniques to link the choice for certain products (means) with product attributes and values (ends).

The question is whether and how the values as defined by Schwartz can be linked with the TPB model. Although values are specifically defined as criteria that enable people to guide behaviour, the fact that values are abstract constructs means that many actions are only indirectly related to values and that the empirical relation between personal values and behaviour is generally low (Munson, 1984, Brunso et al., 2004). Values may shape behaviour in a value-congruent direction as far as they are activated during the pre-decisional process. According to de Boer et al. (2006) the indirect impacts of values may operate via specific combinations of involvement, attitudes and some closely related concepts. This applies in particular to food choices, where very strong habits and preferences may create favoured combinations of use situations, meals, products and ingredients. The link between values and attitude is explained by the Expectancy-Value Model of Attitudes (Fishbein and Ajzen, 1975, Ajzen, 2001, Ajzen and Fishbein, 2008) that states that an individual's Attitude (A) is the sum of the salient beliefs (b) concerning the attributes of objects or actions multiplied with the evaluations (e) (values) attached or $A=\Sigma b_{i} e_{i}$. The link between values and attitude is supported by empirical research and this also for (natural and organic) food purchase (Goldsmith et al., 1997, Homer and Kahle, 1988, de Boer et al., 2006, Thøgersen, 2007a). Dreezens et al. (2005) have found that the value "universalism" has a positive correlation and the value "power" has a negative correlation with the attitude towards organic food. Opposite correlations between these values and the attitude towards genetically modified (GM) food have been found. However the relations between the values and the attitudes are mediated by beliefs for both organic and GM food. Based on a dataset of 1113 Danish respondents, Thøgersen (2007a), reported that attitudes towards organic food consumption depend primarily on beliefs about consequences (better for the environment, tastes better, healthier, ...), whereas basic values and past experience provided 
more marginal direct contributions to explained variance. However the significant correlations between values, respectively experience, and beliefs suggest that the latter two constructs have a stronger total (i.e. direct plus indirect) effect on attitudes than their regression coefficients indicate. In the integrated framework in Figure 1, we therefore indicated that values influence the formation of attitudes and we also indicated the moderation of beliefs.

Recent studies also point to the influence of "personal norm" or "moral norm" on the attitude towards purchasing organic food (Thøgersen, 2002, Arvola et al., 2008). The influence of personal norm on organic food purchase (intention) may be stronger than or incorporate the influence of subjective (social) norm (Thøgersen and Olander, 2006, Dean et al., 2008). Schwartz (1973) mentioned that when people who are called to act lack clearly formulated personal norms toward specific actions, they can crystallise norms based on their general values. Arvola (2008) and Manstead (2000) find that personal norm plays an important role in translating the universal values from Schwartz (1992) into attitude. Also the role of "emotions" (Verhoef, 2005, Dean et al., 2008) on organic food consumption has been mentioned in recent research. This has led us to indicate in the integrated framework, the interactions between emotions on one hand and attitude, intention and behaviour on the other. These concepts are discussed in more detail in the next section.

\section{Determinants of organic food consumption}

The integrated framework presented in Figure 1 is used in this section for structuring the literature concerning determinants of organic food consumption.

\subsection{Values as motivators for organic food consumption}

Interesting features of values in comparison with attitudes are first that they are more stable in time, because they are more centrally connected to an individual's cognitive system (Rokeach, 1973) and second, that with a limited set of ten values one can incorporate virtually all specific values from different cultures around the world (Schwartz, 1992). Several authors use the value approach (Schwartz, 1992) to get better insight in the consumption of food produced by organic or sustainable farming systems. Most of them apply the means-end-chain approach (Gutman, 1982, Costa et al., 2004) to link product attributes with one of the ten values identified by Schwartz (1992). In this section we discuss the values that have been related to organic food consumption. The explanations behind each of the mentioned values below are based on Schwartz (2006).

SECURITY - Safety, harmony, and stability of society, of relationships, and of oneself. Several studies concluded that health, which is linked with the value security, is the strongest motive for purchasing organic food (Schifferstein and Oude Ophuis, 1998, Worner and MeierPloeger, 1999, von Alvensleben, 2001, Chinnici et al., 2002, Harper and Makatouni, 2002, Makatouni, 2002, Zanoli and Naspetti, 2003, Mintel, 2003, Millock et al., 2004, Chryssohoidis and Krystallis, 2005, Padel and Foster, 2005, Shepherd et al., 2005, Baltussen et al., 2006, Botonaki et al., 2006, Bonti-Ankomah and Yiridoe, 2006, Chen, 2009). Also other researchers have found a significant relation between consumer's health-related attitudes and their purchases 
of organic food: Torjusen et al. (1999), Magnusson et al. (2003), McEachern and Willock (2004), Organic Centre Wales (2004), Arbindra et al. (2005), Durham and Andrade (2005), Lea and Worsley (2005), Midmore et al. (2005), Gracia and de Magistris (2007) and Stobbelaar et al. (2007).

HEDONISM - pleasure and sensuous gratification for oneself.

Magnusson et al. (2001) found that good taste is the most important purchase criterion among Swedish consumers ( $\mathrm{n}=1154)$ when buying food (milk, meat, potatoes and bread). Stobbelaar et al. (2007) found that for Dutch adults' taste is the most important motive for buying organic products. The Taylor Nelson Sofres report stated that taste and food safety concerns are the most important factors in persuading people to try organic food for the first time and in encouraging UK consumers to increase spending on organic products (Organic Centre Wales, 2004). Roddy et al. (1996) Schifferstein and Oude Ophuis (1998), McEachern and McClean (2002) and Fotopoulos et al. (2003) indicated that taste is an important factor to buy organic products in Ireland, The Netherlands, Scotland and Greece, respectively. Also Chryssohoidis and Krystallis (2005) found a significant relation between the importance Greek consumers attach to "fun and enjoyment" and the consumption of organic fresh fruits and vegetables. Zanoli and Naspetti (2002) reported that Italian consumers of organic products associate organic products to health at different levels of abstraction and search for good, tasty and nourishing products, because pleasure and well-being are their most important values. Kihlberg and Risvik (2007) found that the majority of organic consumers think that organic food tastes better than conventional.

STIMULATION - Excitement, novelty, and challenge in life.

People may be triggered to learn more about organic products as new products on the market and therefore purchase them. This is related to the concept of "Exploratory Buying Behaviour Tendency" (EBBT). Fotopoulos and Krystallis (2002a, 2002b) revealed the existence of a consumer cluster exhibiting strong EBBT as the main motive of organic preference. Chinnici (2002) reported that for $23.1 \%$ of Sicilian consumers the main reason for choosing organic products was curiosity.

UNIVERSALISM - understanding, appreciation, tolerance, and protection for the welfare of all people and for nature. Several studies support the finding that the propensity to behave in an environment-friendly way in general is related more to universalism than to any other value (Thøgersen and Olander, 2003). As organic food production turns out to be more environmentalfriendly for some aspects (De Backer et al., 2009, Mondelaers et al., 2009a) and is certainly perceived as more environment-friendly by most consumers (Hoefkens et al., 2009, Mondelaers et al., 2009b), one can expect a positive relation between "universalism" and organic food consumption. Based on a consumer survey study of 1,000 respondents from each of eight European countries, performed within the CONDOR project $(n=8113)$, it was concluded, that among Schwartz's ten motivational domains, Universalism is the only or the dominant value guiding consumers' purchase of organic food (Thøgersen, 2007a). Krystallis et al. (2008) found that universalism and benevolence are the most important values when it comes to predicting regular organic consumption. Dreezens et al. (2005) found that respondents who score high on universalism, rated organic food as positive. Lea and Worsley (2005) found that personal values related to nature, environment and equality are positively predicting pro-organic food beliefs. A lot of studies identify a clear relation between the importance consumers attach to the environment and their attitude and behaviour towards organic products (Grunert and Juhl, 1995, Schifferstein and Oude Ophuis, 1998, Torjusen et al., 1999, Loureiro et al., 2001, Magnusson et 
al., 2001, Magnusson et al., 2003, Millock et al., 2004, Organic Centre Wales, 2004, Durham and Andrade, 2005, Kuhar and Juvancic, 2005, Midmore et al., 2005, Padel and Foster, 2005, Verhoef, 2005, Gracia and de Magistris, 2007, Stobbelaar et al., 2007, Chen, 2009). Also animal welfare is reported as an important motivation for buying organic meat (Harper and Makatouni, 2002, Hill and Lynchehaun, 2002, McEachern and Willock, 2004, Aarset et al., 2006, Chen, 2007, Lind, 2007, Pouta et al., 2008).

However, Chryssohoidis and Krystallis (2005) find that among their Greek consumer sample care for the environment and nature are not relevant for organic food purchase. Interestingly, also the study by Baker et al.(2004) revealed that UK consumers made no connection between organic food consumption and care for the environment, while German consumers did make this connection.

Finally, the studies from Magnusson et al.(2001), Zanoli and Naspetti (2003), Padel and Foster (2005), Krystallis et al. (2008) and Mondelaers et al. (2009b) find that transcendental values such as Universalism and Benevolence are more important for regular organic food consumers than for occasional organic food consumers.

BENEVOLENCE - preserving and enhancing the welfare of those with whom one is in frequent personal contact (the 'in-group'). Padel and Foster (2005) find that only a minority of their respondents associate organic products with local production, stating that they like to buy organic because it supports the local economy and makes them "feel good". This points to a current weakness and future challenge for the organic sector as an important share of organic food in Europe is currently imported. Padel et al. (2008) report that on average (only) 66 percent of the organic primary produce sold by multiple retailers in the UK were sourced from the UK in 2006 and that with demands outpacing supply imports are likely to increase.

SELF DIRECTION - independent thought and action; choosing, creating, exploring.

Some people may consume organic food to differentiate themselves from others, to give them a positive self-image and identity. Chryssohoidis and Krystallis (2005) found a significant relation between the importance Greek consumers attached to "self-respect" and the consumption of organic fresh fruits and vegetables. Stobbelaar et al.(2007) also found that adolescents belonging to families that support more charitable funds have a more positive attitude towards organic food. A relevant hypothesis is that the need for self-actualisation ("do something positive with life") is at stake here. Another potential explanation may relate to the impact of the value CONFORMITY.

CONFORMITY - Restraint of actions, inclinations, and impulses likely to upset or harm others and violate social expectations or norms.

This value influences "subjective norm" via the motivation to comply with the expectations of others. The influence of subjective norm on organic food consumption is described in detail in section 3.6.

POWER- Social status and prestige, control or dominance over people and resources. Dreezens et al. (2005) found that when consumers scored high on the value power (dominance versus submission), they rated organic food more negatively and genetically modified food more positively. 


\subsection{Attitude}

According to the expectancy-value theory (Fishbein and Ajzen, 1975, Ajzen, 2001, Ajzen and Fishbein, 2008) attitudes result from the multiplication of beliefs with their evaluations. This approach was adopted by Saba and Messina (2003) on a sample of 947 Italian consumers, who tended to hold positive attitudes towards eating organic fruits and vegetables. They agreed, on average, that organic fruits and vegetables were healthy, environmentally friendly, and more tasty and nutritious than conventionally grown foods. The summed products of beliefs towards these products with the related outcome evaluations provided a high contribution to the prediction of attitudes. Attitude was found to be a significant predictor of intention of eating organic fruits and vegetables. Based on a dataset of 1113 Danish consumers, Thøgersen (2007a) reported that attitudes towards organic tomatoes and tomato juice depend on beliefs about consequences, whereas basic values and past experience give more marginal direct contributions. According to Thøgersen's study especially beliefs about health, taste and environmental consequences have the strongest influence on attitude towards buying organic tomato (juice), which is in line with Saba and Messina (2003), whereas beliefs towards cost have relatively little influence on the attitude.

\subsection{Cognitive and affective components of attitude}

Attitudes contain both cognitive (thinking) and affective (feeling) components (Ajzen and Driver, 1991, Ajzen, 2001, Agarwal and Malhotra, 2005, Kim et al., 2007). The multicomponent view of attitude assumes that evaluations are influenced by cognition as well as affect (Ajzen, 2001). Agarwal and Malhotra (2005) showed that the interactions between both components influence attitude and choice. Individuals differ in their tendency to base their attitudes on cognition or affect and in this sense one can sometimes differentiate between "thinkers" and "feelers". Attitudes toward some objects may rely more on affect (e.g. computer games) while more on cognition in the case of other objects (e.g. grammar checking program) (Ajzen, 2001). Referring to Conner and Sparks (1996) who claim that food consumption is heavily laden with affect, Dean et al. (2008) measured both attitude components related to organic apple and pizza purchase and found that both affect and cognition are relevant to predict purchase intention. This suggests that people evaluate behaviour not only in terms of costs and benefits, but also in terms of the positive and negative feelings generated. Dean et al. (2008) argue that also for the purchase of organic food, affect and cognition combine in a compensatory way. More concrete, e.g. perceived costs of buying organic products may be offset by the positive feelings that it produces. In this context it is worth to mention the finding of Lavine et al. (1998) that when beliefs and feelings regarding an object are of opposite valence, feelings tend to predominate. Ajzen (2001) reports that response times are significantly shorter for affective judgments than for cognitive judgements suggesting that the affective aspects underlying attitudes are more easily accessible in memory. These findings highlight the importance of including both affective and cognitive components of attitudes in behaviour models in general and in food choice models in particular where affect plays an important role on purchase intention. In this context, it is important to mention that the current scientific research remains inconclusive, and thus fuels uncertainty about important cognitive aspects of organic food, e.g. healthiness. We assume that for people who recognise this uncertainty this may reduce the value of a cognitive approach, and they may rely more on their feelings (affective processing) in forming a personal attitude towards organic food. 


\subsection{Emotions - as the strongest affective response}

Peter et al. (1999) distinguish between four broad types of affective response: evaluations, moods, specific feelings and emotions. These types of response differ in the intensity with which they are experienced (level of bodily arousal). Emotions involve the strongest physiological response.

Laros and Steenkamp (2005) propose that different levels of detail can be used to study emotions and that more detail leads to greater explanatory power of consumer behaviour. At the superordinate level, they only distinguish between positive and negative affect; at the basic level they distinguish four positive (contentment, happiness, love, and pride) and four negative emotions (sadness, fear, anger, and shame) and at the subordinate level, they distinguish between 42 specific emotions.

Verhoef (2005) found that emotions can determine purchasing behaviour of organic meat. Among the three emotions studied (fear, guilt and empathy), especially "fear" impacts on consumers' purchase decision. That "fear" may influence organic meat purchase behaviour is not surprising as fear is driven by uncertainty (Lerner and Keltner, 2000, Watson and Spence, 2007). Abbot (2001), Verbeke (2001) and Pennings et al.(2002) found that due to the recent food crises in the meat industry, consumers may feel that their health is at risk when consuming meat. Perugini and Bagozzi (2001) tested an adapted and extended form of TPB, and found that anticipated emotions have significant and important influence on desires, which determine intentions, which in turn influence (goal-directed) behaviour.

Kaiser (2006) and Bamberg and Möser (2007) find that extending TPB with "anticipated feelings of moral regret (guilt)" helps to explain the variance of intention to behave conservationally by using less natural resources. Guilt is defined as a "painful feeling of regret that is aroused when the actor actually causes, anticipates causing, or is associated with an aversive event according to personal or subjective norms. Guilt is an important pro-social emotion. Bamberg and Möser (2007) find that "feelings of guilt" directly influence moral norm, attitude and PBC, while feelings of guilt are influenced by problem awareness, social norm and internal attribution.

\subsection{Attitude influencing intention}

The Theory of Reasoned Action (TRA) (Fishbein and Ajzen, 1975, Ajzen and Fishbein, 2005) indicates that "attitude" is an important predictor of "behavioural intention" and this has been confirmed in numerous studies. Also in the case of organic food consumption TRA and TPB seem to be consistent, e.g. the study from Saba and Messina (2003). Chen (2007), Thøgersen (2007a) and Dean et al. (2008) report a significant positive relation between consumers' intention to purchase organic food and their attitude to organic food purchase, subjective norm and PBC. Gracia and de Magistris (2007) conclude that organic food purchases are positively and significantly linked with the intention to purchase organic food, a positive attitude towards organic products with respect to health and environmental benefits, and a higher (perceived) behavioural control (higher levels of income and knowledge). Also Tarkiainen and Sundqvist (2005) find a positive and significant relation between the attitude towards buying organic food and the intention to buy. 


\subsection{Subjective norm or social norms}

Subjective norm is the perceived social pressure for a person to engage or not to engage in a behaviour. It is assumed that subjective norm is determined by the total set of accessible normative beliefs concerning the expectations of important referents for this person (e.g. family or friends) (Ajzen, 2006). The importance of social norms for environmentally responsible behaviour is thoroughly documented in the literature (Biel and Thøgersen, 2007, Thøgersen, 2007b). In the context of food choice, Vermeir and Verbeke (2006) reported that the desire to comply with other people could explain strong intentions to purchase sustainable dairy products despite weak personal attitudes. Applied to organic food consumption, Chen (2007), Thøgersen (2007b) and Dean et al. (2008) find a significant positive relation between consumers' intention to purchase organic food and their subjective norm. Gotschi et al. (2007) find that for Austrian adolescents, primary socialisation, i.e. the norms and values learnt at home, have a significant influence on the development of a positive attitude towards organic food, while secondary socialisation, e.g. at the school environment, has less impact on attitude formation. Tarkiainen and Sundqvist (2005) find no direct significant path relation between subjective norm and intention to buy organic, but rather a significant positive path relation between subjective norm and attitude towards organic food consumption. The reviews on TPB applications from Ajzen (1991) and Armitage and Conner (2001) indicate that subjective norm often exerts no direct effect on intention after checking for the effects of attitude and PBC (Bamberg et al., 2007). Using meta-analytical Structural Equation Modelling, Bamberg et al. (2007) find that subjective norm has no direct association with intention, but rather an indirect effect by influencing attitude, PBC, moral norm and feelings of guilt in a context of pro-environmental behaviour. When both subjective and personal norms are included in models in the analysis, environmentally responsible behaviour is usually accounted for by the latter rather than the former of these two norm constructs (Thøgersen, 2007b).

It is assumed that people frequently follow social norms not (only) because they fear social pressure, but because they give information about what behaviour is most appropriate or beneficial (Jager, 2000, Bamberg et al., 2007).

\subsection{Personal norm or moral norm}

According to Schwartz (1973) personal norms refer to an individual's conviction that acting in a certain way is right or wrong and when people do not yet have clearly formulated personal norms toward specific actions, when called upon to act, they can crystallise norms based on their general values According to Schwarz (1977) "activated personal norms" are experienced as feelings of moral obligations. Personal norms are sometimes referred to as internalised social norms, other times as the product of reasoning about a behaviour's moral consequences (Thøgersen, 2007b).

Extant research contains plenty of evidence linking variations in environmentally responsible behaviour to the strength of individuals' (personal) norms (Thøgersen, 2007b). Relatively recent research suggests that including a measure of personal norm or moral norm in the TPB model, especially in morally relevant situations, can improve the explanatory power of this model (Armitage and Conner, 2001, Godin et al., 2005, Kaiser et al., 2005, Kaiser, 2006, Bamberg et al., 2007, Bamberg and Moser, 2007). From a philosophical point of view, a situation is considered to be morally relevant when one's self-interest and the interest of others are at odds with each other (Manstead, 2000). This is a conflict that relates to many currently existing environmental problems (Kaiser et al., 2005). In the context of organic food consumption this 
may be relevant as the price premium individuals face may be a purchase barrier and conflict with the interest to buy a more environment friendly product. Indeed recent studies point out that personal norm has a significant influence on the intention towards purchasing organic food (Thøgersen, 2002, Thøgersen and Olander, 2006, Arvola et al., 2008, Dean et al., 2008). Both the studies from Thøgersen and Olander (2006) and from Dean et al. (2008) have found that the effect of personal norm on organic food purchase (intention) is stronger than the effect of subjective (social) norm.

Thøgersen (2002) found that the outcome of consumers' choice between organic and non organic wine depends on their personal (moral) norms, after controlling for attitudes and subjective social norms. However, the influence of personal norms depended on whether or not the consumer had direct experience of buying organic red wine. Among (wine) consumers who, in the past, never bought organic red wine, personal norms have a marginal influence on choice, whereas among consumers who have bought organic red wine at least occasionally in the past, the influence of personal norms is nearly as strong as that of attitudes. In contrast Thøgersen (2002) did not find any effects of direct experience on attitude strength. Thøgersen and Olander (2006) found that past purchase of organic food products strengthens an individual's personal norms about buying organic food and leads to favourable changes in beliefs about the costs as well.

Schwartz (1973) found that the multiplicative interaction of "Ascribed Responsibility to the self (AR)" $x$ "personal norm" helps significantly explain behaviour related to bone marrow donation. These finding have led to the Norm-Activation Model (NAM) (Schwartz, 1977). The basic premise of the NAM is that moral or personal norms are direct determinants of pro-social behaviour (Schwartz, 1977, Bamberg and Moser, 2007). The Value-Belief-Norm theory (VBN) (Stern, 2000) links value theory to norm-activation theory by generalizing the latter. It postulates that the consequences that matter in activating personal norms are adverse consequences to whatever the individual values. The link from values to environmental friendly behaviour is moderated by particular beliefs, such as beliefs about which people or things are affected by environmental conditions and about whether there are individual actions that could alleviate threats (Stern, 2000). Data from several studies indicate that the values most strongly implicated in activating pro-environmental personal norms are, as Norm-Activation theory presumes, altruistic or self-transcendent values. However, other values are sometimes linked as well. Selfenhancement or egoistic values and "traditional" values such as obedience, self-discipline, and family security are negatively associated with pro-environmental norms and action in some studies (Stern, 2000).

Biel and Thøgersen (2007) find that both personal and situational factors are relevant for the activation of norms in social dilemmas. Bamberg's meta-analysis (2007) supports the assumption that in the field of pro-environmental behaviour the formation as well as activation of a moral norm itself is determined by the interplay of cognitive, emotional, and social factors. Problem awareness, internal attribution, feelings of guilt, and social norms all significantly contribute to the prediction of moral norm. Together these four predictors explain $58 \%$ variance of moral norm.

An interesting finding from Hubner and Kaiser (2006) is that moral considerations have a stronger effect on a person's behavioural intention in cases of conflicts between attitude and subjective norm, compared to cases of harmonic attitudes and subjective norms. 
Recent findings indicate that TPB, possibly extended with moral norms influencing intentions, outperforms VBN (Kaiser et al., 2005) and NAM (Bamberg and Moser, 2007) to explain proenvironmental behaviour. Bamberg and Möser's meta-analysis (2007), based on information from a total of 57 studies, finds that pro-environmental behavioural intention mediates the impact of all other psycho-social variables on pro-environmental behaviour.

\subsection{Perceived behavioural control (PBC)}

Ajzen (2005) reported a gap between "attitude towards a behaviour" and the "behaviour" itself. Ajzen (1991) explained this by stating that (perceived) barriers and (perceived) abilities may interfere and includes this interference in the Theory of Planned Behaviour through the factor of (Perceived) Behavioural Control. PBC refers to people's own perception about their ability to perform a given behaviour. It is determined by beliefs about the presence of factors that may facilitate or impede performance of the behaviour (Ajzen, 2006). Dean et al. (2008) find a significant positive effect from $\mathrm{PBC}$ on the intention to buy organic apples, however this relation was not significant for organic pizza. Also findings from Thøgersen (2007a) confirm TPB and herein the role of PBC in a model explaining purchases of organic fresh tomatoes and organic tomato sauce. Below we discuss some "perceived barriers" that may impede and "perceived abilities" that may facilitate behavioural intention and behaviour of consuming organic food.

\subsubsection{Perceived barriers: price, availability, lack of trust and product appearance}

With respect to consumption of sustainable food products several authors such as Wempe (2000), Burell and Vrieze (2003), Padel and Foster (2005) and Vermeir and Verbeke (2006) have reported a gap between consumer attitude and their claimed or marketplace behaviour. Tarkiainen and Sundqvist (2005) mention that in the majority of earlier studies, consumers hold positive attitudes towards organic food, while the proportion of consumers who purchase organic food on a regular basis remains quite low. The main consumption barriers for organic food found in literature are the relatively high price premium (Hill and Lynchehaun, 2002, 2001, Magnusson et al., 2001, Tregear et al., 1994, Batt and Giblett, 1999, Padel and Foster, 2005, Lea and Worsley, 2005, McEachern and Willock, 2004, Vindigni et al., 2002, Organic Centre Wales, 2004, Botonaki et al., 2006, Fotopoulos and Krystallis, 2002b, Worner and Meier-Ploeger, 1999, O'Donovan and McCarthy, 2002, Zanoli and Naspetti, 2002, Hughner et al., 2007, Byrne et al., 1991) and the real or perceived lack of availability (Vindigni et al., 2002, Chryssohoidis and Krystallis, 2005, Lea and Worsley, 2005, Makatouni, 2002, Mintel, 2000, Botonaki et al., 2006, Fotopoulos and Krystallis, 2002b, Worner and Meier-Ploeger, 1999, O'Donovan and McCarthy, 2002, Rodríguez et al., 2008, Zanoli and Naspetti, 2002, Hughner et al., 2007). Additional elements mentioned are uncertainty (Thøgersen, 2007a) or the lack of information, low knowledge (Padel and Foster, 2005, Makatouni, 2002, McEachern and McClean, 2002, Aarset et al., 2006), and lack of trust in the organic certification process (Padel and Foster, 2005, Lea and Worsley, 2005, Aarset et al., 2006, Hughner et al., 2007, Krystallis et al., 2008).

\subsubsection{Perceived abilities: income}

Following Jager (2000) and Ajzen (2006) differences in abilities such as financial resources may have a strong impact on the performance of behaviour. Gracia and de Magistris (2007) and Bonti-Ankomah and Yiridoe (2006) report that according to several empirical studies (Hill and Lynchehaun, 2002, Torjusen et al., 2001, 2002, Kuhar and Juvancic, 2005, Tsakiridou et al., 2006, Fotopoulos and Krystallis, 2002b, Sandalidou et al., 2002, Arbindra et al., 2005, Denver et al., 2007) income seems to play a significant positive role in explaining organic food 
purchases in Europe, while in the USA several studies did not find this relation to be significant (Loureiro et al., 2001, Durham and Andrade, 2005, Onyango et al., 2007, Zepeda and Li, 2007, Jolly and Norris, 1991, Goldman and Clancy, 1991, Buzby and Skees, 1994, Wilkins and Hillers, 1994, Wolf, 2002). Studies in Canada (e.g., Hay, 1989; Cunningham, 2002) reported a positive relationship between income and willingness to buy organic products, up to a given level of income. Lockie et al.(2002) find that the proportion of Australians consuming organic food rises when income increases. Riefer and Hamm (2008) found that changes in organic food consumption also arise in relation to changes in the situation of income. Thus, in some cases interviewees described that due to their partners' unemployment organic food consumption was limited. Kenanoğlu and Karahan (2002) indicate that in Turkey the limited sales of organic products is mainly due to the average low income of people and the considerable price premium for organic products.

\subsection{From intention to behaviour}

Several studies have found that the path from intentions of buying organic food to the behaviour is positive and significant (e.g. Tarkiainen and Sundqvist, 2005, Thøgersen, 2007a, Saba and Messina, 2003).

\subsection{Socio-demographic factors}

Socio-demographic factors and macro-level factors (e.g. culture, technology, ...) are not mentioned explicitly in the Theory of Values and TPB, however they are present implicitly, as consumer groups segmented based on differences in socio-demographic factors may also differ in relation to attitude, intentions or behaviour. We give an overview of the current findings about socio-demographic factors on organic food consumption in this section and of macro-level factors in section 3.11 .

Lea and Worsley (2005) and Worner and Meier-Ploeger (1999) report that values are a stronger predictor of positive organic food beliefs than socio-demographic variables. Also Gracia and de Magistris (2007) find that consumers' socio-demographic characteristics have limited influence on organic food purchases, concerning both the intention to purchase and the final decision. In their study only income has a significant and positive influence. However in some studies significant influences of socio-demographic variables have been found.

Gender. Stobbelaar et al.(2007) refer to studies that indicate that 'soft' values (e.g. ecofriendliness) seem to better fit female perspectives and that women are generally more concerned about health and healthy food. Stobbelaar et al.(2007) and Gotschi et al. (2007) find that adolescent girls are more positive towards organic products than boys. Lea and Worsley (2005), Lockie et al. (2004) and Koivisto Hursti (2003) and Magnusson (2001) have found that a higher proportion of women than men hold positive attitudes towards organic food. Byrne (Byrne et al., 1991), Davies et al. (1995), Lockie et al. (2002), McEachern and McClean (2002), O'Donovan and McCarthy (2002), Storstad and Bjorkhaug (2003), Arbindra et al. (2005) and Radman (2005) report that a higher proportion of women are purchasers or consumers of organic food.

Children. Davies et al. (1995), Thompson and Kidwell (1998), McEachern and Willock (2004), Freyer and Haberkorn (2008) and Yue (2008) have found that families with children were more likely to buy organic produce. On the contrary Loureiro and Hine (2002) found a (negative but) non-significant relation between children in the household and the willingness to pay for organic 
products, which they explain due to a lower disposable income of these households. Hill and Lynchehaun (2002), Freyer and Haberkorn (2008) and Riefer and Hamm (2008) report that following a child-birth experience, mothers changed their feeding patterns, using more organic products in their daily menu and mostly for the whole family. The most quoted argument for organic products is the need to secure the health of children. Additionally, concrete health problems of their own children or of other family members led to an increased consumption of organic products. Riefer and Hamm (2008) found that households share of organic food consumption may decrease when children enter their adolescence and develop own food preferences.

Age. Some authors have found a significant relation between age and the consumption of organic food. However, findings are not always consistent. For example, Geen and Firth (2006) find that in the UK, committed organic consumers tend to be older than the average population, while Arbindra et al. (2005) find on the contrary that older respondents were less likely to buy organic foods than younger respondents. Mintel (2003) reported that the most common purchasers of organic vegetables in the UK are 45-54 year olds. Magnusson et al.(2001) reported that young (18-25 years) in contrast to older respondents have a more positive attitude towards organic foods, and perceived it more likely that they would buy an organic alternative. However, since there were no differences between age groups with respect to purchase frequency, the results suggest that, in spite of their stronger interest, young consumers do not buy organic foods more frequently than elderly. Davies et al. (1995) and O'Donovan and McCarthy (2002) do not find significant differences between age groups concerning the purchase of organic vegetables. Lea and Worsley (2005) find that the impact of age on organic food beliefs is minimal. Taking into account the relevant body of literature as a whole, we follow Fotopoulos and Krystallis (2002b) claiming that age does not seem to play an important role in shaping organic food consumption.

Education. Also education seems not to play an important role in relation to organic food consumption. Some authors find a positive relation between education and organic food consumption (Jolly, 1991, Wandel and Bugge, 1997, Cunningham, 2002, O'Donovan and McCarthy, 2002, Sandalidou et al., 2002, Hay, 1989, Denver et al., 2007, Yue et al., 2008), while others find a negative relation (Byrne et al., 1991, Buzby and Skees, 1994, Wilkins and Hillers, 1994, Thompson and Kidwell, 1998). Lea and Worsley (2005) find that the impact of education on organic food beliefs is minimal. Arbindra et al. (2005) finds that the level of education has no statistically significant influence on organic food purchase patterns.

\subsection{Macro-level factors}

Individual choices may be influenced by factors in the macro environment. Macro-level factors that are potentially of importance in the consumption of organic food are (i) the functioning of institutions (e.g. legislation, control, the presence and functioning of market channels), (ii) the environment people are living in; (iii) cultural differences; (iv) economic factors; (v) general knowledge and (vi) technological factors. Below we discuss some of these factors.

\section{Region}

The fact that $97 \%$ of consumer demand for organic food is concentrated in North America and Europe (Sahota, 2009) clearly indicates strong differences between regions in the world, with probably purchasing power playing the most important role. Also within Europe important differences exists with the highest per capita expenditure on organic food in 2006 in Switzerland (102€), Denmark (80€) and Austria (64€) and still very low expenditures per capita in Central 
European countries, e.g. Poland, Hungary and Slovak Republic each about $1 €$ per capita in 2006 (Padel et al., 2008).

Zanoli (2004) indicates that also other factors determine differences between countries in the development of their organic markets. Based on focus group discussions in France, Germany, Switzerland, Italy and the United Kingdom, Zanoli et al. (2007) highlighted major differences in attitudes, beliefs and understanding of consumers in these five countries with regard to organic and low input products. Important factors are: (i) general consumer knowledge about and trust in organic food; (ii) the participation of food retailers in the organic market, (iii) the importance of the existing price premiums. Other explanations for differences between countries are different food habits and socio-cultural influences, e.g. in Southern European countries food has a strong social connotation and enjoyment of eating together with other people is important (Zanoli, 2004). Zanoli (2004) also reports that taste is by no doubt the most important attribute in food choice in general, though the concrete taste experience is quite subjective and is very much influenced by culture. Also Valli and Traill (2005) suggest that important cultural differences continue to determine food-related behaviour in 11 European countries they studied.

Thøgersen (2007a) found that the reasons given and the reasoning behind choosing organic products are quite similar across eight European countries. However, the gap between intention and behaviour is larger in the Southern countries. This may in part be explained by a higher degree of uncertainty and the lower availability of organic food in these countries where food quality orientations are rather focused on geographical indications such as Protected Designations of Origin or Protected Geographical Indications (Becker, 2009, Verbeke and Roosen, 2009).

\section{Rural versus urban living area}

Differences in attitude may exist between people living in a rural or urban area. Midmore et al. (2005) and Denver et al. (2007) report that in Denmark, household organic shares are higher in urban areas, especially in the capital area. The lowest shares are observed in western rural areas. However, McEachern and Willock (2004) identified only few attitudinal and motivational differences between rural and urban consumers in the UK with respect to the consumption of organic meat. O'Donovan and McCarthy (2002) find no significant differences between consumers from a rural or urban background and their organic food purchase intentions.

\section{The functioning of institutions}

The organic product market can be considered as an emerging market. Since the 1990s it has experienced rapid growth and in Europe supermarket chains have become the sales channel with the largest market share and are the main driver for further growth (Aertsens et al., 2009). Also recently Sahota (2009) reported that high growth in the German market is partly because of the entry of the major retailers. Eisenbach (2002) describes the development of the organic market in Greece in four stages and compares it with Germany. This growth process involves the adoption of organic products by different sales channels, a scaling up in volume and broadening of the assortment, improving the functioning of supply chains and organising import and export of organic products in order to more flexibly balance domestic supply and demand or organic products. This evolution is beneficial for the sales of organic products by increasing the availability of organic products and reducing distribution costs. Padel and Midmore (2005) state that "short supply chains and a focus on regional organic shops may be an indication of an earlier stage of market development, likely to be followed by integration into mainstream outlets 
and involvement of multiple retailers". Torjusen et al. (2004) mention that in countries in which supermarket sales have taken the lead, there has been an increase in both supply and demand. Aertsens et al. (2009) show that strategies largely differ among supermarket chains. Some have advantages from starting to offer organic products in an early stage, while others may benefit more from entering only in a later stage of market development.

A recent study in Buenos Aires, Argentina, indicates that lack of availability, lack of a reliable regulatory system and lack of a common national label constrain consumption of organic products (Rodríguez et al., 2008).

Oughton and Ritson (2007) and von Alvensleben (2001) indicate that part of the increase in consumption of organic products in European countries is driven by supply side activities often stimulated by government support, resulting in more competitive prices and increased availability.

\section{The importance of involvement and uncertainty on mental processing applied to organic food consumption}

In developed countries, the weekly shopping for groceries has mostly been regarded as a low involvement activity (Hoyer, 1984, Beharrell and Denison, 1995, Costa et al., 2004, Fischer and De Vries, 2008). Individuals tend to be in a more habitual or "automated" mode when buying food and may therefore fail to consider alternatives to what they usually buy. Vermeir and Verbeke (2006) have found that consumers that are more involved with sustainable products also hold a more positive attitude and a higher behavioural intention to buy them. Krystallis et al. (2008) mention that the involvement with the organic purchasing process remains on average rather limited. Studies suggest that this is one of the reasons why fewer people than expected buy organic products (Grankvist and Biel, 2001, Thøgersen and Olander, 2006). Vuylsteke et al. (2004) argue that individuals with a positive attitude towards organic food may restrain from buying because they are used to buy non organic food and will not easily change their habits as involvement with food is too low. Effectively, Magnusson et al. (2001) refer to Mathisson and Schollin (1994) who found that $22 \%$ of the Stockholm consumers who did not buy organic vegetables did so because of habit and convenience. Strong habitual behaviour limits the search for information and may block the activation of norms in shaping behaviour (Klöckner et al., 2003). Grunert and Juhl (1995) suggest that high involvement in comparison with low involvement decisions are more susceptible to the influence of values. de Boer et al. (2006) mention that typically, persons with a high level of involvement in an issue tend to make more informed choices based on relatively active and "open minded" information processing. They found that the degree of involvement in food as such was positively correlated with buying "free-range" meat. That involvement may matter importantly in the adoption process of organic food is also indicated by the waves of adoption of organic food that followed crises in the conventional food sector (Aertsens and Van Huylenbroeck, 2004, Aertsens et al., 2009).

Jager's (2000) meta-model of human behaviour focuses on the type of cognitive processes that people use and the role of involvement and uncertainty on these processes. This model may help to better understand the process of breaking with routine or habitual behaviour. Jager identified two dimensions along which cognitive-processing theories can be organised: "reasoned" versus "automated" processes on one hand and "individually" versus "socially" determined processing 
on the other. Combining these dimensions results in four categorisations of behaviour: (1) Repetition; (2) Imitation; (3) Deliberation and (4) Social comparison (Figure 2). Jager assumes that people usually employ only one type of cognitive processing at a time.

Figure 2: Role of involvement and uncertainty in cognitive processing (Jager, 2000)

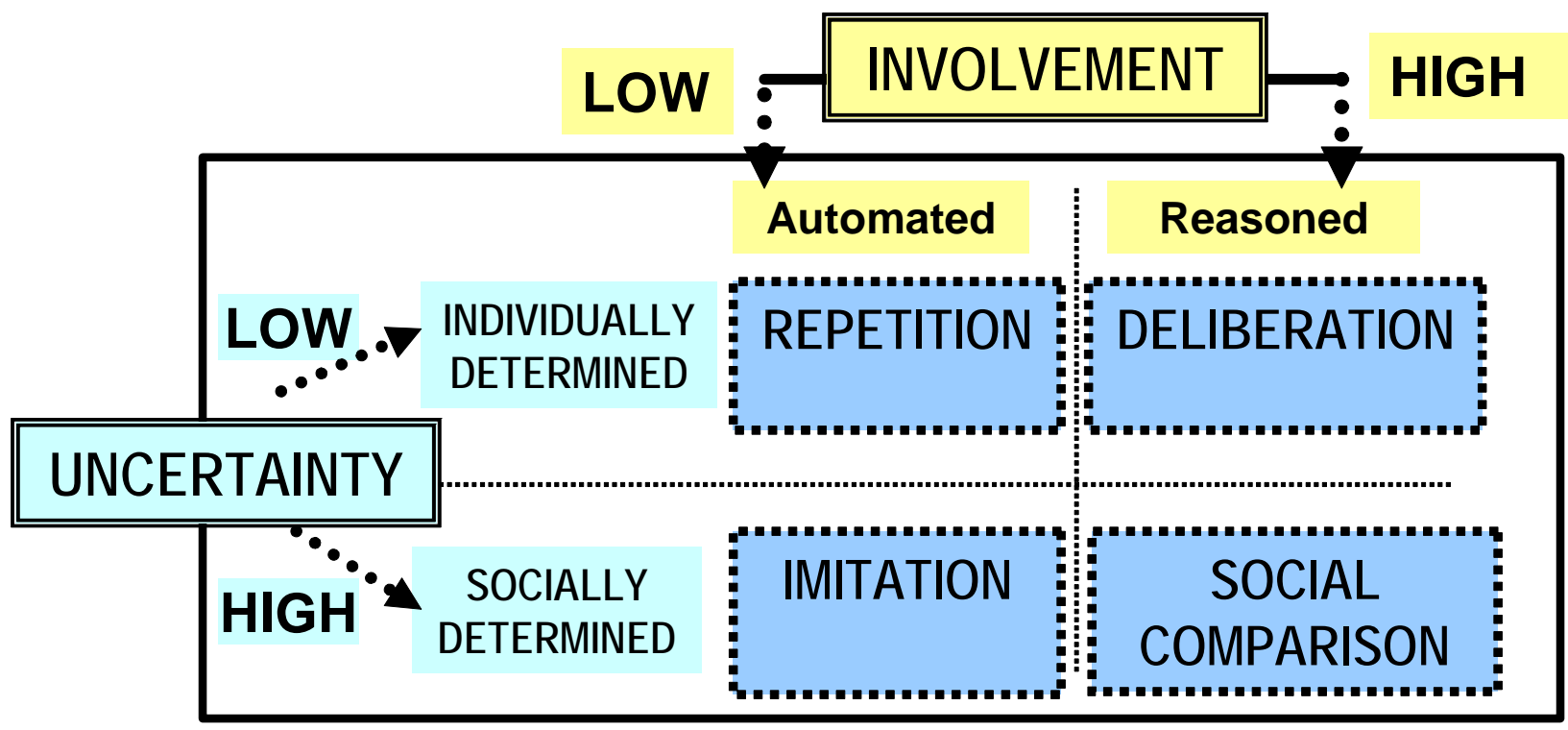

Habitual behaviour is an effective means of coping with strong demands on our conscious attention and limited problem-solving ability (Thøgersen and Olander, 2006). Reasoned processing requires more time and energy. Therefore it will more often take place when the consequences are important enough, in other words when involvement or personal relevance is high. For actions with low involvement one will often apply automated processing. Involvement will generally be higher if the level of need satisfaction is lower (Jager, 2000). Jager's model considers 'Needs' as the main driving force or motivator behind human behaviour, referring to the theories from Maslow (1954) and Max-Neef (1992). As indicated by Beckmann and Hansen (1999) there is a strong match between the concept of these "Needs" and the concept of "Values" in the Values Theory, as values can be defined as cognitive-emotive representations of three types of universal human requirements or needs.

Sometimes occasions occur when involvement is higher and people may be triggered to step out of this automated routine, e.g. when there is a food crisis or for special occasions like organising a party. In such circumstances they may step out of a routine behaviour and be motivated to reason and consider a wider range of possibilities than they usually do. In such cases, especially when consumers look for safety and/or quality buying organic food may be considered.

We set forth the hypothesis that especially in the case of values/needs that are highly important for the individual, and in cases where the level of need satisfaction is rather low and consequently according to Jager (2000) involvement is very high, emotions may have an important impact on behaviour. Future research could explore this further. Applied to the consumption of organic food, Aertsens and Van Huylenbroeck (2004) describe that the dioxin and BSE food scares in Europe between 1995 and 2002, have caused some consumers to switch to organic food consumption. We believe that certain consumers at that period perceived conventional food to be insufficiently safe and the consequent low level of satisfaction with 
respect to the need for safe food and resulting higher involvement and concern for their health, may have triggered them to act and switch to consuming organic food.

Also according to Jager (2000) higher uncertainty about the consequences of behaviour, is expected to increase the impact of the subjective norm. Future research could test the hypothesis that "The more uncertainty individuals have about the consequences of organic food consumption, the more they will be influenced by subjective norm, ceteris paribus". Applied to organic food this can be understood as that uncertainty about the effects of organic food will trigger people to follow the behaviour of others they observe and as a majority of people rarely or not buy organic products, uncertainty may make that people will be more likely to restrain from purchasing organic food. Thøgersen (2007a) found that if people feel uncertain about organic food they are less likely to make a decision to buy it, in spite of favourable attitudes and norms. Uncertainty may relate to e.g. the question whether (organic) food is healthy, whether organic certification can be trusted, and even whether organic food is considered as fashionable.

It seems interesting for future research to further study the role of involvement and uncertainty in relation to organic food consumption.

\section{Concluding discussion}

In this paper, we structured the main literature findings related to personal determinants of organic food consumption within an integrated framework. We believe this structuring of literature gives a better insight in the interactions between the different relevant factors that influence organic food consumption. Although we are not in a position to quantify all relations in the integrated framework (this would require a large scale survey in different countries), the structured analysis of literature findings contributes to a better understanding of the discrepancy between attitudes measures in surveys and the real behaviour of people with respect to purchasing organic food.

The usefulness of the TPB in the case of organic food consumption has been demonstrated by several studies. We can conclude that organic purchases are positively and significantly related to intentions to purchase in combination with (perceived) behavioural control. Intentions are in turn influenced by the attitude, (personal and subjective) norms and (perceived) behavioural control. Recent studies indicate that including personal norms (Thøgersen, 2002, Thøgersen and Olander, 2006, Arvola et al., 2008, Dean et al., 2008) and emotions within the TPB model may help explaining organic food purchases. Verhoef (2005) has shown that fear has a significant influence on organic meat purchases, which can be related to the food scares in the conventional sector.

Values are important stable motivators for behaviour as they provide more abstract goals towards which behaviour is targeted. Egocentric values are stronger motivators for organic food purchase than altruistic values, which is not unexpected for people familiar with the consumercitizen paradox (Johnston, 2008). The review indicates that health, related to the value security, is the strongest argument for purchasing organic food. Also taste, related to the value hedonism, can play an important role in determining organic food purchases. The value universalism has a positive influence too. It is important that one is careful not to generalise, as significant differences seem to exist between consumer segments: (1) The value universalism, incorporating protection of the environment and nature and animal welfare, seems to play a 
more important role for more regular consumers of organic food and adolescents (Chinnici et al., 2002, Schifferstein and Oude Ophuis, 1998, Zanoli and Naspetti, 2002, Krystallis et al., 2008, Mondelaers et al., 2009b); (2) in different countries, different values might be more strongly related to organic food consumption: e.g. in Greece (Chryssohoidis and Krystallis, 2005) environmental friendliness related to "universalism" seemed to play no important role, while in other countries this seemed to be important; (3) girls are found to attach more importance to the relation between organic food and animal welfare (Stobbelaar et al., 2007). This information is very relevant for e.g. marketers promoting organic products in order to focus on the right values, those that increase involvement within the targeted consumer segment.

Related to these findings we believe it would be interesting if future research would focus more on a detailed description of the values, attitude, involvement, motivations and barriers of different user segments (e.g. non-, light-, medium- and heavy users). Getting more insight herein may be very relevant as the group of light and medium users have important potential for future market growth.

Attitudes towards organic food are on average positive (Saba and Messina, 2003). The strongest related beliefs are that organic food is healthy, environmentally friendly, and more tasty than conventionally grown foods.

PBC may facilitate or hamper the step from intention to behaviour. While purchasing power is probably a strong factor explaining that $97 \%$ of all organic food is consumed in Europe and North-America and several authors find that household income has a significant positive correlation with organic food purchases in Europe, Canada and Australia, also a lot of studies did not find a significant effect of income on organic food purchases in the USA. The strongest barriers for organic food consumption are the price premium and the lack of availability of organic products. To lower the gap between the intention to purchase organic food and the actual purchase, improving availability and easiness to access organic food, e.g through the integration in mainstream sales channels and lower price premiums are important. The impact of price reductions on demand are expected to be important as price elasticity of organic food is a lot higher than for conventional food (Wier and Calverley, 2002). Resulting growth of sales may lead to economies of scale that may further reduce supply costs. In this way there can be an evolution towards a new market equilibrium at a considerable higher level of supply and demand volume. Also, if more consumers adopt buying organic food their behaviour may be imitated by others.

Other barriers that may have received insufficient attention are uncertainty among consumers about different attributes of organic food among which the lack of trust in the certification process. It is very important to reduce this uncertainty, as Thøgersen (2007a) indicates that even among people who hold favourable attitudes and norms towards organic food, uncertainty about organic food may reduce the likeliness of purchase. In the framework proposed by Jager (2000) this can be understood as uncertainty promotes people to follow the behaviour of others and a majority of people rarely or not buy organic products. Providing extra information about the production and control processes of organic food, may help reducing the uncertainty and may also help to increase knowledge. As some studies find that a better knowledge also helps to improve the attitude towards organic food (McEachern and McClean, 2002, Gracia and de Magistris, 2007, Stobbelaar et al., 2007) and also increases the willingness to pay a price premium (Barnes et al., 2009), this may be very rewarding . 
Extra knowledge about organic production processes may also help to increase involvement. This is important as food is generally considered a low involvement commodity in developed countries. Therefore most consumers when buying (organic) food will apply an automated rather than reasoned cognitive process. For those people who want to stimulate the organic food market, a resulting crucial question is whether other than negative environmental factors such as negative publicity following a food scarce, may increase involvement and jolt some consumers out of their routine of buying conventional food.

It would be interesting for future research to shed more light on how involvement towards organic food can be further increased. Also there is yet little focus on the process of adoption of organic food. Also the role of emotions, especially fear (and to a lesser extent guilt) should be further explored, as waves of adoption of organic food have been often related to crises in the conventional food sector (Aertsens and Van Huylenbroeck, 2004, Aertsens et al., 2009).

Research on the adoption processes may be very interesting as findings could help to stimulate non users to set a crucial first step. Furthermore, as Thøgersen and Olander (2006) indicate, besides jolting consumers out of their established purchasing routines one should secure that the trial experience is sufficiently rewarding to establish a new organic purchasing routine. If the experience of buying organic food is yielding dissatisfaction, e.g. because of a too high price premium or lower quality perception or experience, it is not likely that the organic purchase will be repeated.

Socio-demographic variables seem to play a limited role in predicting organic food consumption within a region. However, several researchers have reported that a higher proportion of women hold a positive attitude and purchase organic food more often than men. Some studies find that families with children are more likely to buy organic. The findings concerning age and education seem not to be consistent when considering the whole body of literature.

To conclude, we summarise that Values Theory and TPB help importantly to understand organic food consumption. We recommend that researchers and actors in the organic sector would focus more on the importance of affective attitude, including emotions, and the questions on how to increase involvement and reduce uncertainty in relation to organic food consumption.

\section{Acknowledgement}

The authors gratefully acknowledge the suggestions of two anonymous referees which certainly helped to improve the paper.

\section{References}

Aarset, B., Beckmann, S., Bigne, E., Beveridge, M., Bjorndal, T., Bunting, J., McDonagh, P., Mariojouls, C., Muir, J., Prothero, A., Reisch, L., Smith, A., Tveteras, R. and Young, J. (2006), "The European consumers' understanding and perceptions of the "organic" food regime: The case of aquaculture", British Food Journal, Vol. 106 No. 2, pp. 93-105.

Abbott, A. (2001), "BSE fallout sends shock waves through Germany", Nature, Vol. 409 No. 6818, pp. 275-275.

Aertsens, J., Mondelaers, K. and Van Huylenbroeck, G. (2009), "Differences in retail strategies on the emerging organic market", British Food Journal, Vol. 111 No. 2, pp. 138-154.

Aertsens, J. and Van Huylenbroeck, G. (2004) "Role and value of a producers' cooperative in small vertical supply chains: the case of an organic beef chain in Belgium". EURESCOconference: Vertical Markets and Cooperative Hierarchies: The role of Cooperatives in 
the International Agri-Food Industry Strategies and Organization of Agri-Food Cooperatives: Quality Assurance and Vertical Coordination. Chania, Greece.

Agarwal, J. and Malhotra, N. K. (2005), "An integrated model of attitude and affect: Theoretical foundation and an empirical investigation", Journal of Business Research, Vol. 58 No. 4, pp. 483-493.

Ajzen, I. (1991), "The Theory of Planned Behavior", Organizational Behavior and Human Decision Processes, Vol. 50 No. 2, pp. 179-211.

Ajzen, I. (2001), "Nature and operation of attitudes", Annual Review of Psychology, Vol. 52, pp. 27-58.

Ajzen, I. (2006) "Theory of Planned Behaviour - Diagram". Icek Ajzen - Homepage: http://people.umass.edu/aizen/tpb.html.

Ajzen, I. and Driver, B. L. (1991), "Prediction of Leisure Participation from Behavioral, Normative, and Control Beliefs - an Application of the Theory of Planned Behavior", Leisure Sciences, Vol. 13 No. 3, pp. 185-204.

Ajzen, I. and Fishbein, M. (2005) The influence of attitudes on behaviour in Albarracín, D., Johnson, B. T. \& Zanna, M. P. (Eds.) The handbook of attitudes. Mahwah, NJ: Erlbaum.

Ajzen, I. and Fishbein, M. (2008), "Scaling and Testing Multiplicative Combinations in the Expectancy-Value Model of Attitudes", Journal of Applied Social Psychology, Vol. 38 No. 9, pp. 2222-2247.

Arbindra, P. R., Moon, W. and Balasubramanian, S. (2005), "Agro-biotechnology and organic food purchase in the United Kingdom", British Food Journal, Vol. 107 No. 2, pp. 84-97.

Armitage, C. J. and Conner, M. (2001), "Efficacy of the theory of planned behaviour: A metaanalytic review", British Journal of Social Psychology, Vol. 40, pp. 471-499.

Arvola, A., Vassallo, M., Dean, M., Lampila, P., Saba, A., Lahteenmaki, L. and Shepherd, R. (2008), "Predicting intentions to purchase organic food: The role of affective and moral attitudes in the Theory of Planned Behaviour", Appetite, Vol. 50 No. 2-3, pp. 443-454.

Baker, S., Thompson, K. E., Engelken, J. and Huntley, K. (2004), "Mapping the values driving organic food choice: Germany vs the UK", European Journal of Marketing, Vol. 38 No. 8, pp. $995-1012$.

Baltussen, W. H. M., Wertheim-Heck, S. C. O., Bunte, F. H. J. and Tacken, G. M. L. (2006) "Een Biologisch Prijsexperiment; Grenzen in zicht?". Universiteit Wageningen.

Bamberg, S., Hunecke, M. and Blobaum, A. (2007), "Social context, personal norms and the use of public transportation: Two field studies", Journal of Environmental Psychology, Vol. 27 No. 3, pp. 190-203.

Bamberg, S. and Moser, G. (2007), "Twenty years after Hines, Hungerford, and Tomera: A new meta-analysis of psycho-social determinants of pro-environmental behaviour", Journal of Environmental Psychology, Vol. 27 No. 1, pp. 14-25.

Barnes, A. P., Vergunst, P. and Topp, K. (2009), "Assessing the consumer perception of the term "organic": a citizens' jury approach", British Food Journal, Vol. 111 No. 2, pp. 155-164.

Batt, P. J. and Giblett, M. (1999), "A pilot study of consumer attitudes to organic fresh fruit and vegetables in Western Australia", Food Australia, Vol. 51 No. 11, pp. 549-50.

Becker, T. (2009), "European Food Quality Policy: The Importance of Geographical Indications, Organic Certification and Food Quality Assurance Schemes in European Countries ", The Estey Centre Journal of International Law and Trade Policy, Vol. 10 No. 1, pp. 111-130.

Beckmann, S. C. and Hansen, F. (1999) "Comparing social psychological and applied value research". Copenhagen, Copenhagen Business School.

Beharrell, B. and Denison, T. J. (1995), "Involvement in a routine food shopping context", British Food journal, Vol. 97 No. 4, pp. 24-29. 
Biel, A. and Thøgersen, J. (2007), "Activation of social norms in social dilemmas: A review of the evidence and reflections on the implications for environmental behaviour", Journal of Economic Psychology, Vol. 28, pp. 93-112.

Bonti-Ankomah, S. and Yiridoe, E. K. (2006) "Organic and Conventional Food: A Literature Review of the Economics of Consumer Perceptions and Preferences". Organic Agriculture Centre of Canada

Botonaki, A., Polymeros, K., Tsakiridou, E. and Mattas, K. (2006), "The role of food quality certification on consumers' food choices", British Food Journal, Vol. 108 No. 2-3, pp. 77-90.

Brunso, K., Scholderer, J. and Grunert, K. G. (2004) "Closing the gap between values and behavior - a means-end theory of lifestyle". International Research Seminar on Marketing Communications and Consumer Behavior. La Londe, France, Elsevier Science Inc.

Burell, A. and Vrieze, G. (2003), "Ethical motivation of Dutch egg consumers", Tijdschrift voor Sociaalwetenschappelijk onderzoek van de Landbouw, Vol. 18 No. 1, pp. 30-40.

Buzby, J. C. and Skees, J. (1994), "Consumers want reduced exposure to pesticides in food", Food Review, Vol. 17 No. 2, pp. 19-22.

Byrne, P. J., Toensmeyer, U. C., German, C. L. and Muller, H. R. (1991), "Analysis of Consumer Attitudes Toward Organic Produce and Purchase Likelihood", Journal of Food Distribution Research, Vol. 22, pp. 49-62.

Chen, M. F. (2007), "Consumer attitudes and purchase intentions in relation to organic foods in Taiwan: Moderating effects of food-related personality traits", Food Quality and Preference, Vol. 18 No. 7, pp. 1008-1021.

Chen, M. F. (2009), "Attitude toward organic foods among Taiwanese as related to health consciousness, environmental attitudes, and the mediating effects of a healthy lifestyle", British Food Journal, Vol. 111 No. 2, pp. 165-178.

Chinnici, G., D'Amico, M. and Pecorino, B. (2002), "A multivariate statistical analysis on the consumers of organic products", British Food Journal, Vol. 104 No. 3/4/5, pp. 187-199.

Chryssohoidis, G. M. and Krystallis, A. (2005), "Organic consumers' personal values research: Testing and validating the list of values (LOV) scale and implementing a value-based segmentation task", Food Quality and Preference, Vol. 16 No. 7, pp. 585-599.

Conner, M. and Armitage, C. J. (1998), "Extending the theory of planned behavior: A review and avenues for further research", Journal of Applied Social Psychology, Vol. 28 No. 15, pp. 1429-1464.

Conner, M. and Sparks, P. (1996) The Theory of Planned Behaviour and health behaviours. Predicting health behaviour: Research and practice with social cognition models. Buckingham; UK, Open University Press.

Costa, A. I. A., Dekker, M. and Jongen, W. M. F. (2004), "An overview of Means-End theory: potential application in consumer-oriented food product design", Trends in Food Science \& Technology, Vol. 15 No. 7-8, pp. 403-415.

Cunningham, R. (2002) "Who is the Organic Consumer? ". A Paper presented at Growing Organic Conference. Alberta.

Davies, A., Titterington, A. J. and Cochrane, C. (1995), "Who buys organic food? A profile of the purchasers of organic food in Northern Ireland", British Food Journal, Vol. 97, pp. 17-23.

De Backer, E., Aertsens, J., Vergucht, S. and Steurbaut, W. (2009), "Assessing the ecological soundness of organic and conventional agriculture by means of life cycle assessment (LCA) - a case study of leek production", British Food Journal. 
de Boer, J., Hoogland, C. T. and Boersema, J. J. (2006) "Towards more sustainable food choices: Value priorities and motivational orientations". 2nd European Conference on Sensory Consumer Science of Food and Beverages. The Hague, Netherlands.

Dean, M., Raats, M. M. and Shepherd, R. (2008), "Moral concerns and consumer choice of fresh and processed organic foods", Journal of Applied Social Psychology, Vol. 38 No. 8, pp. 2088-2107.

Denver, S., Christensen, T. and Krarup, S. (2007) "How vulnerable is organic consumption to information?". Nordic Consumer Policy Research Conference; Towards a new consumer? Towards a new policy? Helsinki.

Dreezens, E., Martijn, C., Tenbult, P., Kok, G. and de Vries, N. K. (2005), "Food and values: an examination of values underlying attitudes toward genetically modified- and organically grown food products", Appetite, Vol. 44 No. 1, pp. 115-122.

Durham, C., A and Andrade, D. (2005) "Health vs. environmental motivation in organic preferences and purchases.". American Agricultural Economics Association Annual Meeting. Providence, Rhode Island.

Eisenbach, J. (2002), "Distribution channels for Greek organic food in the domestic and international market", British Food Journal, Vol. 104 No. 3/4/5, pp. 214-219.

Fischer, A. R. H. and De Vries, P. W. (2008), "Everyday behaviour and everyday risk: An approach to study people's responses to frequently encountered food related health risks", Health Risk \& Society, Vol. 10 No. 4, pp. 385-397.

Fishbein, M. and Ajzen, I. (1975) Belief, Attitude, Intention, and Behaviour: An Introduction to Theory and Research., New York, USA., J. Wiley \& Sons.

Fotopoulos, C. and Krystallis, A. (2002a), "Organic product avoidance: Reasons for rejection and potential buyers identification in a countrywide survey", British Food Journal, Vol. 104 No. 9, pp. 730-765.

Fotopoulos, C. and Krystallis, A. (2002b), "Purchasing motives and profile of the Greek organic consumer: A countrywide survey", British Food Journal, Vol. 104 No. 3/5, pp. 232-260.

Fotopoulos, C., Krystallis, A. and Ness, M. (2003), "Wine produced by organic grapes in Greece: using means-end chains analysis to reveal organic buyers' purchasing motives in comparison to non-buyers", Food Quality and Preference, Vol. 14, pp. 549-66.

Freyer, B. and Haberkorn, A. (2008) " Influence of Young Children (3-6 years) on Organic Food Consumption in their Families". 16th IFOAM Organic World Congress; Cultivating the Future Based on Science. Modena, Italy.

Geen, N. and Firth, C. (2006) "The comitted organic consumer". Joint Organic Congress. Odense, Denmark.

Godin, G., Conner, M. and Sheeran, P. (2005), "Bridging the intention-behaviour 'gap' : The role of moral norm ", British journal of social psychology, Vol. 44 No. 4, pp. 497-512.

Goldman, B. J. and Clancy, K. L. (1991), "A survey of organic produce purchases and related attitudes of food cooperative shoppers", American Journal of Alternative Agriculture, Vol. 6 No. 2, pp. 89-96.

Goldsmith, R. E., Frieden, J. and Henderson, K. V. (1997), "The impact of social values on food-related attitudes ", British Food Journal, Vol. 99 No. 9, pp. 352-357.

Gotschi, E., Vogel, S. and Lindenthal, T. (2007) "High school students' attitudes and behaviour towards organic products: survey results from Vienna". In Institute for Sustainable Economic Development, D. o. E. a. S. S., University of Natural Resources and Applied Life Sciences (Ed.). Vienna.

Gracia, A. and de Magistris, T. (2007), "Organic food product purchase behaviour: a pilot study for urban consumers in the South of Italy", Spanish Journal of Agricultural Research, Vol. 5 No. 4, pp. 439-451. 
Grankvist, G. and Biel, A. (2001), "The importance of beliefs and purchase criteria in the choice of eco-labeled food products", Journal of Environmental Psychology, Vol. 21 No. 4, pp. 405-410.

Grunert, S. C. and Juhl, H. J. (1995), "Values, environmental attitudes, and buying of organic foods", Journal of Economic Psychology, Vol. 16, pp. 39-62.

Gutman, J. (1982), "A Means-End-Chain Model based on Consumer Categorisation Processes", Journal Of Marketing, Vol. 46 No. 2, pp. 60-72.

Harper, G. and Makatouni, A. (2002), "Consumer perception of organic food production and farm animal welfare", British Food Journal, Vol. 104 No. 3/4/5, pp. 287-299.

Hay, J. (1989), "The consumer's perspective on organic food", Canadian Institute of Food Science Technology Journal, Vol. 22 No. 2, pp. 95-99.

Hill, H. and Lynchehaun, F. (2002), "Organic milk: Attitudes and consumption patterns", British Food Journal, Vol. 104 No. 7, pp. 526-542.

Hoefkens, C., Verbeke, W., Aertsens, J., Mondelaers, K. and Van Camp, J. (2009), "The nutritional and toxicological value of organic vegetables: consumer perception versus scientific evidence", British Food Journal

Homer, P. M. and Kahle, L. R. (1988), "A Structural Equation Test of the Value-AttitudeBehavior Hierarchy", Journal of Personality and Social Psychology, Vol. 54 No. 4, pp. 638-646.

Hoyer, W. D. (1984), "An examination of consumer decision-making for a common repeat purchase product", Journal of Consumer Research, Vol. 11 No. 3, pp. 822-829.

Hubner, G. and Kaiser, F. G. (2006), "The moderating role of the attitude-subjective norms conflict on the link between moral norms and intention", European Psychologist, Vol. 11 No. 2, pp. 99-109.

Hughner, R. S., McDonagh, P., Prothero, A., Shultz, C. J. and Stanton, J. (2007), "Who are organic food consumers? A compilation and review of why people purchase organic food", Journal of Consumer Behaviour, Vol. 6, pp. 1-17.

Jager, W. (2000) "Modelling consumer behaviour". University of Groningen, $240 \mathrm{p}$.

Johnston, J. (2008), "The citizen-consumer hybrid: ideological tensions and the case of Whole Foods Market", Theory and Society, Vol. 37 No. 3, pp. 229-270.

Jolly, D. A. (1991), "Differences between buyers and nonbuyers of organic produce and willingness to pay organic price premiums. ", Journal of Agribusiness Vol. 9 No. 1, pp. 97-111.

Jolly, D. A. and Norris, K. (1991), "Marketing prospects for organic and pesticide-free produce", American Journal of Alternative Agriculture, Vol. 6 No. 4, pp. 174-179.

Kaiser, F. G. (2006), "A moral extension of the theory of planned behavior: Norms and anticipated feelings of regret in conservationism", Personality and Individual Differences, Vol. 41 No. 1, pp. 71-81.

Kaiser, F. G., Hubner, G. and Bogner, F. X. (2005), "Contrasting the theory of planned behavior with the value-belief-norm model in explaining conservation behavior", Journal of Applied Social Psychology, Vol. 35 No. 10, pp. 2150-2170.

Kenanoğlu, Z. and Karahan, Ö. (2002), "Policy implementations for organic agriculture in Turkey.", British Food Journal, Vol. 104 No. 3-4-5, pp. 300-318.

Kihlberg, I. and Risvik, E. (2007), "Consumers of organic foods - value segments and liking of bread", Food Quality and Preference, Vol. 18 No. 3, pp. 471-481.

Kim, H. W., Chan, H. C. and Chan, Y. P. (2007), "A balanced thinking-feelings model of information systems continuance", International Journal of Human-Computer Studies, Vol. 65 No. 6, pp. 511-525. 
Klöckner, C. A., Matthies, E. and Hunecke, M. (2003), "Problems of Operationalizing Habits and integrating Habits in Normative Decision-Making Models", Journal of Applied Social Psychology, Vol. 33 No. 2, pp. 396-417.

Koivisto Hursti, U. K. and Magnusson, M. K. (2003), "Consumer perceptions of genetically modified and organic foods: what kind of knowledge matters?", Appetite, Vol. 41, pp. 207-9.

Krystallis, A., Vassallo, M., Chryssohoidis, G. and Perrea, T. (2008), "Societal and individualistic drivers as predictors of organic purchasing revealed through a portrait value questionnaire (PVQ)-based inventory", Journal of Consumer Behaviour, Vol. 7, pp. 164-187.

Kuhar, A. and Juvancic, L. (2005) "Modelling consumer preferences towards organic and integrated fruits and vegetables in Slovenia". 97th EAAE Seminar on The Economics and Policy of Diet and Health. Reading, UK.

Laros, F. J. M. and Steenkamp, J. (2005), "Emotions in consumer behavior: a hierarchical approach", Journal of Business Research, Vol. 58 No. 10, pp. 1437-1445.

Lavine, H., Thomsen, C., Zanna, M. and Borgida, E. (1998), "On the primacy of affect in the determination of attitudes and behavior: the moderating role of affective-cognitive ambivalence", Journal of Experimental Social Psychology, Vol. 34, pp. 398-421.

Lea, E. and Worsley, T. (2005), "Australians' organic food beliefs, demographics and values", British Food Journal, Vol. 107 No. 11, pp. 855-869.

Lerner, J. S. and Keltner, D. (2000), "Beyond valence: Toward a model of emotion-specific influences on judgement and choice", Cognition \& Emotion, Vol. 14 No. 4, pp. 473-493.

Lind, L. W. (2007), "Consumer involvement and perceived differentiation of different kinds of pork - a Means-End Chain analysis", Food Quality and Preference, Vol. 18 No. 4, pp. 690-700.

Lockie, S., Lyons, K., Lawrence, G. and Grice, J. (2004), "Choosing organics: a path analysis of factors underlying the selection of organic food among Australian consumers", Appetite, Vol. 43 No. 2, pp. 135-146.

Lockie, S., Lyons, K., Lawrence, G. and Mummery, K. (2002), "Eating green: motivations behind organic food consumption in Australia", Sociologia Ruralis, Vol. 42 No. 1, pp. 23-40.

Loureiro, M., L and Hine, S. (2002), "A comparison of consumer willingness to pay for a local (Coloradogrown), organic, and GMO-free product", Journal of Agricultural \& Applied Economics Vol. 34 No. 3, pp. 477-487.

Loureiro, M. J., McCluskey, J. J. and Mittelhammer, R. C. (2001), "Assessing consumer preferences for organic, eco-labeled, and regular apples", Journal of Agricultural and Resource Economics, Vol. 26 No. 2, pp. 404-416.

Magnusson, M. K., Arvola, A., Koivisto Hursti, U., Aberg, L. and Sjödén, P. O. (2001), "Attitudes towards organic foods among Swedish consumers", British Food Journal, Vol. 103 No. 3, pp. 209-226.

Magnusson, M. K., Arvola, A., Koivisto Hursti, U., Aberg, L. and Sjöden, P. O. (2003), "Choice of organic foods is related to perceived consequences for human health and to environmentally friendly behaviour", Appetite, Vol. 40 No. 2, pp. 109-117.

Makatouni, A. (2002), "What motivates consumers to buy organic food in the UK?: Results from a qualitative study", British Food Journal, Vol. 104, pp. 345-352.

Manstead, A. (2000) The role of moral norm in the attitude-behavior relation. in Terry, D. J. \& Hogg, M. A. (Eds.) Attitudes, behaviour and social context: The role of norms and group membership. Amsterdam.

Maslow, A. (1954) Motivation and personality, New York, Harper\& Row. 
Mathisson, K. and Schollin, A. (1994) "Konsumentaspekter pa ekologiskt odlade grönsaker - en jämförande studie (Consumer aspects on organic vegetables - a comparative study)". In Department of Crop Production Sciences, S. U. o. A. S. (Ed.).

Max-Neef, M. (1992) Development and human needs. in Ekins, P. \& Max-Neef, M. (Eds.) Reallife economics: Understanding wealth creation. . London, New York, Routledge.

McEachern, M. G. and McClean, P. (2002), "Organic purchasing motivations and attitudes: are they ethical?", International Journal of Consumer Studies, Vol. 26 No. 2, pp. 85-92.

McEachern, M. G. and Willock, J. (2004), "Producers and consumers of organic meat: a focus on attitudes and motivations", British Food Journal, Vol. 106 No. 7, pp. 534-52.

Midmore, P., Naspetti, S., A-M, S., Vairo, D., Wier, M. and Zanoli, R. (2005) "Consumer Attitudes to Quality and Safety of Organic and Low Input Foods: a review".

Millock, K. and Hansen, L. G. (2002) "Willingness to Pay for Organic Foods: A Comparison between Survey Data and Panel Data from Denmark". EAERE (European Association of Environmental and Resource Economists) Conference. Monterey, USA.

Millock, K., Wier, M. and Andersen, L. M. (2004) "Consumer's demand for organic foodsattitudes, value and purchasing behaviour". Selected paper for presentation at the XIII Annual Conference of European Association of Environmental and Resource Economics. Budapest, Hungary.

Mintel (2000) "Organic food and drink retailing". London, Martket intelligence unit of the UK economist intelligence unit.

Mintel (2003) "organic Foods". In UK, M. I. G. (Ed.). London.

Mondelaers, K., Aertsens, J. and Van Huylenbroeck, G. (2009a), "A meta-analysis of the differences in environmental impacts between organic and conventional farming", British Food Journal.

Mondelaers, K., Verbeke, W. and Van Huylenbroeck, G. (2009b), "Importance of health and environment as quality traits in the buying decision of organic products", British Food Journal.

Munson, J. M. (1984) personal values: considerations on their measurement and application to five areas of research inquiry. in Pitss, R. E. W. A., editors; (Ed.) Personal values and consumer psychology. Lexington Books.

O'Donovan, P. and McCarthy, M. (2002), "Irish consumer preference for organic meat", British Food Journal, Vol. 104, pp. 353-370.

Onyango, B. M., Hallman, W. K. and Bellows, A. C. (2007), "Purchasing organic food in US food systems - A study of attitudes and practice", British Food Journal, Vol. 109 No. 45, pp. 399-411.

Organic Centre Wales (2004) "Organic Food: Understanding the consumer and increasing sales". In Agency, T. W. D., Wales, O. C. \& Association, S. (Eds.) Taylor Nelson Sofres. Aberystwyth, UK.

Oughton, E. and Ritson, C. (2007) Food consumers and organic agriculture. in Cooper, J., Leifert, C. \& Niggli, U. (Eds.) Handbook of organic food quality and safety. Abington, Cambridge, England, Woodhead Publishing Ltd; sales@woodhead-publishing.com.

Padel, S. and Foster, C. (2005), "Exploring the gap between attitudes and behaviour Understanding why consumers buy or do not buy organic food", British Food Journal, Vol. 107 No. 8, pp. 606-625.

Padel, S., Jasinka, A., Rippin, M., Schaack, D. and Willer, H. (2008) The European Market for Organic Food in 2006. in Willer, H., Yussefi-Menzler, M. \& Sorensen, N. (Eds.) The World of Organic Agriculture - Statistics and Emerging Trends 2008. Bonn, IFOAM and FIBL. 
Padel, S. and Midmore, P. (2005), "The development of the European market for organic products: Insights from a Delphi study", British Food Journal, Vol. 107 No. 8, pp. 626647.

Padel, S., Schaak, D. and Willer, H. (2009) Development of the Organic Market in Europe. in Willer, H. \& Kilcher, L. (Eds.) The World of Organic Agriculture. Statistics and Emerging Trends 2009. FIBL-IFOAM Report.

Pennings, J. M. E., Wansink, B. and Meulenberg, M. T. G. (2002), "A note on modeling consumer reactions to a crisis: The case of the mad cow disease", International Journal of Research in Marketing, Vol. 19 No. 1, pp. 91-100.

Perugini, M. and Bagozzi, R. P. (2001), "The role of desires and anticipated emotions in goaldirected behaviours: Broadening and deepening the theory of planned behaviour", British Journal of Social Psychology, Vol. 40, pp. 79-98.

Peter, J. P., Olson, J. C. and Grunert, K. G. (1999) Consumer behaviour and marketing strategy, Berkshire, England, McGraw-Hill.

Pouta, E., Forsman-Hugg, S., Heikkila, J., Isoniemi, M., Makela, J. and Paananen, J. (2008) "Consumers' choice of broiler meat in Finland: the effects of country of origin and production methods". EAAE 2008 Congress: People, Food and Environments: Global trends and European Strategies. Ghent, Belgium, August 26-29.

Radman, M. (2005), "Consumer consumption and perception of organic products in Croatia", British Food Journal, Vol. 107 No. 4-5, pp. 263-273.

Riefer, A. and Hamm, U. (2008) "Changes in Families' Organic Food Consumption". 12th Congress of the European Association of Agricultural Economists - EAAE 2008. Ghent; Belgium.

Roddy, G., Cowan, C. and Hutchinson, G. (1996), "Consumer attitudes and behaviour to Organic foods in Ireland", Journal of International Consumer Marketing, Vol. 9 No. 2, pp. 1-19.

Rodríguez, E., Lacaze, V. and Lupín, B. (2008) "Contingent Valuation of Consumers' Willingness-to-Pay for Organic Food in Argentina". 12th Congress of the European Association of Agricultural Economists - EAAE. Ghent, Belgium.

Rokeach, M. J. (1973) The nature of human values, New York, The Free Press.

Saba, A. and Messina, F. (2003), "Attitudes towards organic foods and risk/benefit perception associated with pesticides", Food Quality and Preference, Vol. 14, pp. 637-645.

Sahota, A. (2009) The Global Market for Organic Food \& Drink. in Willer, H. \& Kilcher, L. (Eds.) The World of Organic Agriculture, Statistics and Emerging Trends 2009. Bonn, FIBL-IFOAM Report.

Sandalidou, E., Baourakis, G. and Siskos, Y. (2002), "Customers perspectives on the quality of organic olive oil in Greece: A satisfaction evaluation approach", British Food Journal, Vol. 104, pp. 391-406.

Schifferstein, H. N. J. and Oude Ophuis, P. A. M. (1998), "Health-related determinants of organic food consumption in the Netherlands", Food Quality and Preference, Vol. 9, pp. 119-133.

Schwartz, S. H. (1973), "Normative Explanations of Helping Behavior: A Critique, Proposal, and Empirical Test", Journal of Experimental Social Psychology, Vol. 9, pp. 349-364.

Schwartz, S. H. (1977) Normative influences on altruism. in Berkowitz, L. (Ed.) Advances in experimental social psychology. New York.

Schwartz, S. H. (1992), "Universals in the Content and Structure of Values: Theoretical Advances and Empirical Tests in 20 Countries", Advances in Experimental Social Psychology, Vol. 25, pp. 1-65 p.

Schwartz, S. H. (2006) "Basic Human Values: An Overview.". The Hebrew University of Jerusalem. 
Shepherd, R., Magnusson, M. and Sjoden, P. O. (2005), "Determinants of consumer behavior related to organic foods", Ambio, Vol. 34 No. 4-5, pp. 352-359.

Stern, P. C. (2000), "Toward a coherent theory of environmentally significant behaviour", Journal of Social Issues, Vol. 56 No. 3, pp. 407-424.

Stobbelaar, D. J., Casimir, G., Borghuis, J., Marks, I., Meijer, L. and Zebeda, S. (2007), "Adolescents' attitudes towards organic food: a survey of 15- to 16-year old school children", International Journal of Consumer Studies, Vol. 31, pp. 349-356.

Storstad, O. and Bjorkhaug, H. (2003), "foundations of production and consumption of organic food in Norway: common attitudes among farmers and consumers", Agriculture and Human values, Vol. 20, pp. 151-163.

Tarkiainen, A. and Sundqvist, S. (2005), "Subjective norms, attitudes and intentions of Finnish consumers in buying organic food", British Food Journal, Vol. 107 No. 10-11, pp. 808822.

Thøgersen, J. (2002), "Direct experience and the strength of the personal norm - Behavior relationship", Psychology \& Marketing, Vol. 19 No. 10, pp. 881-893.

Thøgersen, J. (2007a) Consumer decision-making with regard to organic food products. in Vaz, M. T. d. N., Vaz, P., Nijkamp, P. \& Rastoin, J. L. (Eds.) Traditional Food Production Facing Sustainability: A European Challenge; Ashgate.

Thøgersen, J. (2007b) "The motivational roots of norms for environmentally responsible behaviour". Nordic Consumer Policy Research Conference. Helsinki.

Thøgersen, J. and Olander, F. (2003), "Spillover of environment-friendly consumer behaviour", Journal of Environmental Psychology, Vol. 23 No. 3, pp. 225-236.

Thøgersen, J. and Olander, F. (2006), "The dynamic interaction of personal norms and environment-friendly buying behavior: A panel study", Journal of Applied Social Psychology, Vol. 36 No. 7, pp. 1758-1780.

Thompson, G. D. and Kidwell, J. (1998), "Explaining the choice of organic produce: cosmetic defects, prices, and consumer preferences", American Journal of Agriculture Economics, Vol. 80 No. 2, pp. 277-287.

Torjusen, H., Lieblein, G., Wandel, M. and Francis, C. A. (2001), "Food system orientation and quality perception among consumers and producers of organic food in Hedmark County, Norway", Food Quality and Preference, Vol. 12 No. 3, pp. 207-216.

Torjusen, H., Nyberg, A. and Wandel, M. (1999) "Organic Food; Consumers' Perceptions and Dietary Choices". Statens Institutt for forbruksforkning.

Torjusen, H., Sangstad, L., O’Doherty Jensen, K. and Kjaernes, U. (2004), "European Consumers' conceptions of organic food: a review of available research; p. 147", pp. 147.

Tregear, A., Dent, J. B. and McGregor, M. J. (1994), "The Demand for Organically Grown Produce", British Food Journal, Vol. 96, pp. 21-25.

Tsakiridou, E., Mattas, K. and Tzimitra-Kaloglanni, I. (2006), "The influence of consumer characteristics and attitudes on the demand for organic olive oil", Journal of International Food \& Agribusiness Marketing, Vol. 18 No. 3-4, pp. 23-31.

Valli, C. and Traill, W. B. (2005), "Culture and food: a model of yoghurt consumption in the EU", Food Quality and Preference, Vol. 16 No. 4, pp. 291-304.

Verbeke, W. (2001), "Beliefs, attitude and behaviour towards fresh meat revisited after the Belgian dioxin crisis", Food Quality and Preference, Vol. 12 No. 8, pp. 489-498.

Verbeke, W. and Roosen, J. (2009), "Market differentiation potential of quality-of-origin, quality and tracebility labeling", The Estey Centre Journal of International Law and Trade Policy, Vol. 10 No. 1, pp. 20-35.

Verhoef, P. C. (2005), "Explaining purchases of organic meat by Dutch consumers", European Review of Agricultural Economics, Vol. 32, pp. 245-267. 
Vermeir, I. and Verbeke, W. (2006), "Sustainable food consumption: exploring the consumer "attitude - behavioural intention" gap", Journal of Agricultural and Environmental ethics, Vol. 19 No. 2, pp. in press.

Vindigni, G., Janssen, M. A. and Jager, W. (2002), "Organic food consumption. A multitheoretical framework of consumer decision making", British Food Journal, Vol. 104 No. 8, pp. 624-642.

von Alvensleben, R. (2001) Beliefs associated with Food Production Methods. in Frewer, L. J., Risvik, E. \& Schifferstein, H. (Eds.) Food, People and Society - A European Perspective of Consumer's Food Choices. Springer-Verlag Berlin Heidelberg New York.

von Alvensleben, R. and Bruhn, M. (2001) Verbrauchereinstellungen zu Bioprodukten Ergebnisse einer neuen Langfriststudie, Fakultät der Universität Kiel.

Vuylsteke, A., Vackier, I., Verbeke, W. and Van Huylenbroeck, G. (2004) "Desk study on consumer behaviour towards sustainable food products". XI World Congress of Rural Sociology. Trondheim, Norway.

Wandel, M. and Bugge, A. (1997), "Environmental concerns in consumer evaluation of food quality", Food Quality and Preferences, Vol. 8 No. 1, pp. 19-26.

Watson, L. and Spence, M. T. (2007), "Causes and consequences of emotions on consumer behaviour - A review and integrative cognitive appraisal theory", European Journal of Marketing, Vol. 41 No. 5-6, pp. 487-511.

Wempe, J. (2000) "'Consumentenzorgen' in Nederland. Maatschappelijk verantwoord consumeren". Amstelveen, KPMG Ethics \& Integrity Consulting.

Wier, M. and Calverley, C. (2002), "Market potential for organic foods in Europe", British Food Journal, Vol. 104 No. 1, pp. 45-62.

Wilkins, J. L. and Hillers, V. N. (1994), "Influences of pesticide-residue and environmental concerns on organic food preference among food cooperative members and non-member in Washington-state", Journal of Nutrition Education, Vol. 26 No. 1, pp. 26-33.

Wolf, M. M. (2002) "An Analysis of the Impact of Price on Consumer Interest in Organic Grapes and a Profile of Organic Purchasers.". Long Beach, California, American Agricultural Economics Association Annual Meeting.

Worner, F. and Meier-Ploeger, A. (1999), "What the consumer says", Ecology and Farming, Vol. 20, pp. 14-15.

Yue, c., Grebitus, C., Bruhn, M. and Jensen, H. H. (2008) "Potato Marketing - Factors Affecting Organic and Conventional Potato Consumption Patterns". 12th Congress of the European Association of Agricultural Economists - EAAE. Ghent, Belgium.

Zanoli, R. (2004) "How country-specific are consumer attitudes towards organic food?". annual IBL-meeting: "Looking for a market! Which knowledge is needed for further development of the market on organic farming?". Wageningen (NL).

Zanoli, R., François, M., Midmore, P., O’Doherty-Jensen, K. and Ritson, C. (2007) "Determining consumer expectations, attitudes and buying behaviour towards "low input" and organic foods". 3rd QLIF Congress. Hohenheim, Germany, .

Zanoli, R. and Naspetti, S. (2002), "Consumer motivations in the purchase of organic food: a means-end approach", British Food Journal, Vol. 104 No. 8, pp. 643-653.

Zanoli, R. and Naspetti, S. (2003) "Values and ethics in organic food consumption". 83rd EAAE seminar. Chania, Greece.

Zepeda, L. and Li, J. (2007), "Characteristics of organic food shoppers", Journal of Agricultural Applied Economics, Vol. 39 No. 1, pp. 17-28. 